\title{
Estimation of Water Environment Capacity in the Cau River Basin, Vietnam using the Streeter- Phelps Model
}

\section{Chinh, Le Van}

Laboratory of Water Environment Engineering, Division of Bioproduction Environmental Sciences, Department of Agro-environmental Sciences, Faculty of Agriculture, Kyushu University I

Department of Social and Natural Sciences, Ministry of Science and Technology of Vietnam

\section{Hi ramatsu, Kazuaki}

Laboratory of Water Environment Engineering, Division of Bioproduction Environmental Sciences, Department of Agro-environmental Sciences, Faculty of Agriculture, Kyushu University

\section{Harada, Masayoshi}

Laboratory of Water Environment Engineering, Division of Bioproduction Environmental Sciences, Department of Agro-environmental Sciences, Faculty of Agriculture, Kyushu University

Cuu, Nguyen Trong

Laboratory of Water Environment Engineering, Division of Bioproduction Environmental Sciences, Department of Agro-environmental Sciences, Faculty of Agriculture, Kyushu University | Vietnam Environment Administration, Ministry of Natural Resources and Environment of Vietnam

他

https://doi.org/10.5109/1801777

出版情報：九州大学大学院農学研究院紀要. 62 (1)，pp. 163-169，2017-02-24. Faculty of Agriculture, Kyushu University

バージョン :

権利関係 : 


\title{
Estimation of Water Environment Capacity in the Cau River Basin, Vietnam using the Streeter-Phelps Model
}

\author{
Le Van CHINH ${ }^{*}$, Kazuaki HIRAMATSU, Masayoshi HARADA, \\ Nguyen Trong CUU' ${ }^{2}$ and Truong Thi LAN ${ }^{2}$
}

\author{
Laboratory of Water Environment Engineering, Division of Bioproduction Environmental Sciences, \\ Department of Agro-environmental Sciences, Faculty of Agriculture, \\ Kyushu University, Fukuoka 812-8581, Japan \\ (Received October 11, 2016 and accepted November 4, 2016)
}

\begin{abstract}
Recently, with the acceleration of industrialization, fertilizer and pesticide consumption has increased, leading to intense pollution emission, and rapid increases in pollution load in the Cau River Basin, Vietnam. The main pollutants far exceed their threshold capacities, resulting in deterioration of the function and ecosystem of the river. Therefore, the estimation of the water environment capacity in this river is essential. There are many approaches to address this issue. However, due to a lack of input data and information, researchers are now facing many difficulties in finding a suitable tool for their analysis. This paper introduces a useful model in order to overcome this difficulty. The input data of the areas along the Cau River, such as hydrometeorology data and pollutant sources were collected for the year 2014. Subsequently, water quality component parameters, including total phosphorus (TP), total nitrogen (TN), total suspended solid (TSS), carbon oxygen demand (COD), and biochemical oxygen demand over five days $\left(\mathrm{BOD}_{5}\right)$ that corresponded to different confidence probabilities of surface water discharge, were then computed at some assessment points using the Streeter-Phelps model. Finally, the water environment capacity of this river was assessed by comparing the computed results with the standard values. The results show that most values of the water quality parameters (TP, TN, TSS, COD, and BOD5) in the sub-basins of the Cau River (at assessment points No.1, 2, 3 and 4) far exceeded the standard values, which indicated that the water in the sub-basins was heavily polluted and had low self-cleaning capacities. This could be the contribution of pollutant loads from sub-basins exceeded the standard values. The results serve as useful tools by which managers and authorities can set better goals for different hydrological periods, especially in areas dominated by pollutant sources. They also provide researchers with useful input data and information to help them deal with the environmental issues regarding the Cau River Basin.
\end{abstract}

Key words: self-cleaning, pollutant load, assessment point, sub-basin, water quality

\section{INTRODUCTION}

Water environmental capacity (WEC) is an important concept in environmental science. A basic theory applied in Environmental Impact Assessment (Liu et al., 2012), WEC is the unit load quantity of certain pollutants in a unit time frame, in a unit volume of water, and under the condition that water can fulfill certain environmental objectives (Wang et al., 1995). WEC indicates the capacity of the water body to accept pollutants without its own function being destroyed (Shu and $\mathrm{Ma}, 2010$ ). In general, the water environmental capacity is computed by simple or complex water quality models. Each one has their own powerful tools and strong points. Therefore, the most advantageous method must be chosen based on the available data (Chinh et al., 2015a). However, computation results must be reliable enough in order to meet the actual requirements for assessments (Chinh et al., 2015b).

The biggest advantage of the complex water quality models is that they allow us to focus on the interactions between different components of water quality in river

\footnotetext{
Department of Social and Natural Sciences, Ministry of Science and Technology of Vietnam

2 Vietnam Environment Administration, Ministry of Natural Resources and Environment of Vietnam.

* Corresponding author (E-mail: chinhhec1@yahoo.com)
}

systems, as affected by living and industrial point source pollution (Rinalcli and Soncini-Sessa, 1978), (Wang et al., 2004), and (Cao and Zhang, 2006). Hydrodynamic transmission, sediment oxygen demand, and algal photosynthesis and respiration were considered as external inputs, whereas the non-point source pollution was just taken into account as the background load (Mujumdar and Vemula, 2004) (Riffat, 2012). However, due to the lack of input data and information, researchers are now facing many difficulties in carrying out their simulations and analyses. In those cases, a simple mathematical model should be considered to deal with the urgent issues. One of the simplest, but most powerful models, which has been applied in many cases, is the StreeterPhelps model (Lindenschmidt et al., 2007).

In the past, the simple BOD-DO bilinear system model had been developed and was successful at estimating water quality, and the one-dimensional model was applied to solve pollution issues in rivers and estuaries (Burn and McBean, 1985). After that, most researchers modified and further developed the Streeter-Phelps models (S-P models). For example, Thomas (1948) believed that BOD could be reduced without oxygen consumption due to sediment deposition and flocculation, and the reduction rate was proportional to the quantity of residual BOD; thus, the flocculation coefficient was introduced in to the steady-state S-P model to distinguish 
between the two BOD removal pathways. O'Connor (1967) divided the BOD parameters into carbonized BOD and nitrified BOD and added the effects of dispersion based on the equation. Dobbins (1964) added two coefficients, namely the changing rate of BOD caused by sediment release and surface runoff as well as the changing rate of DO controlled by algal photosynthesis and respiration, to Thomas's equation.

Now day, in order to increase the crop yield production, the farmers put much more fertilizer and pesticide. Beside that, many new factories have been established in recently, therefore the intensity of pollution emission and the pollution load are increasing very quickly in the Cau River Basin, Vietnam. The water quality is affected mainly by runoff, which is responsible for inputting pollutants. Therefore, in this study, using input data such as the pollutant loads from population, livestock, forests and paddy areas, waste water, and the WEC outputs, which include total nitrogen (TN), total phosphorus (TP), total suspended solid (TSS), carbon oxygen demand (COD), and the biochemical oxygen demand over five days $\left(\mathrm{BOD}_{5}\right)$, the WEC at 5 assessment points for the year 2014 were obtained and analyzed based on the StreeterPhelps model. The results of the model were applied to get an overview of the existing WEC, especially in order to identify the weaknesses of the current nutrient management program in the Cau River Basin, Vietnam.

\section{MATERIALS AND METHODS}

\section{Study area}

The Cau River Basin, which is one of the biggest in Vietnam, has an area of $6,030 \mathrm{~km}^{2}$, a length of over $288 \mathrm{~km}$, a rich variety of natural resources, and a long history of development. It plays an important role in the socio-economic development of provinces located in this basin. The flood, environment, and water resource recession are serious problems faced by the population residing in the river basin, causing negative impacts on the environment and sustainable overall development of the river basin. The total water flow of the Cau River Basin is 4.5 billion $\mathrm{m}^{3}$ per annum. The flood season starts from June and lasts until October, and the low water season often lasts for seven to eight months with a water flow of $18-25 \%$ of the total water flow, with the months of lowest water flow being January, February, and March with a rate of $\sim 5-8 \%$ of the total water flow. The Cau River Basin is rich in natural resources, including forests, water, minerals, etc. There are several mineral mines in the basin such as iron, zinc, coal, gold, tin, etc. The average forest cover in the whole basin is about $45 \%$ of the total area. The elements of the natural landscape in the basin have changed considerably. There is no more natural forest cover along rivers and streams. The forest contribution has therefore been significantly depleted, and it is no longer capable of retaining moisture for the dry season and of mitigating flooding in the rainy season. As a result, land has been degraded, with severe floods occurring in the rainy season and long lasting droughts in the dry season. Deforestation, accompanied by socio-eco- nomic development activities such as industry, mining, settlements, and agriculture have placed high pressure on the natural environment of the basin. The basin covers about $47 \%$ of the total natural area of 6 provinces, and holds a population of about 6.9 million (2005), 5.9 million of which live in rural areas, and 1 million live in urban areas. The population density is about 427 persons per $\mathrm{km}^{2}$, which is double the average population density of the whole country. The population density is lowest in the mountainous and midland areas, where $15 \%$ of the total population of the basin live in an area accounting for $63 \%$ of the total basin area. The population density is higher in the urban and central areas. The economy of these provinces depends mostly on agriculture and forestry. In agriculture, chemicals and insecticides are excessively used, especially in the Thai Nguyen province. $\mathrm{NO}_{2}$ and $\mathrm{NO}_{\mathrm{x}}$ contents in the ground are especially high in areas of intensive rice and vegetable cultivation. Therefore, this study focused on the upper part of the Cau River Basin, in order to identify the contribution of the pollutant load to the lower part of the basin and to later provide optimal alternatives to deal with the environmental issues faced by the entire Cau River Basin.

\section{Materials}

Since the aim of this study is to estimate the water environment capacity or self-cleaning ability of the river basin, the assessment points were chosen at locations upstream of the sub-basins and downstream of the main river. Therefore, the water environment capacity of the river basin could be determined by evaluating the concentration of the water quality component parameters.

Fortunately, the daily surface water discharges at five assessment points located upstream of the sub-basins and downstream of the main river, were measured during the period from 1960 to 2014 (Fig. 1). These data were used to compute the flow discharge at the same locations under different confidence probabilities. Besides that, the pollution sources, which are divided

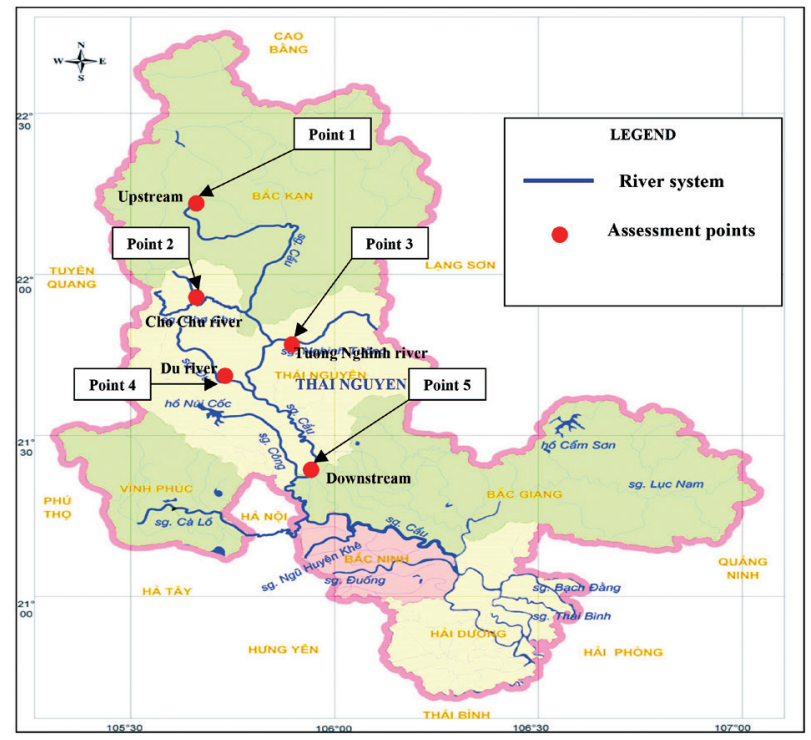

Fig. 1. Location map of the Cau River Basin and study area. 
into three categories of waste water from living activities, waste water from industry, and waste water from agriculture, were collected from the statistic data for the year 2014. These data were used as input data in order to estimate the water quality components such as total phosphorus (TP), total nitrogen (TN), total suspended solid (TSS), carbon oxygen demand (COD), and the biochemical oxygen demand over 5 days (BOD5).

\section{Methodology}

The Streeter-Phelps model has established evaluation model DO and BOD levels from the Ohio River, USA. This is a simple model that estimates the self-cleaning capacity of the river from the effects of biodegradation, sedimentation, and adsorption. In the process flow, the self-cleaning effect will reduce the concentration of organic contaminants in the water. The model used in this study used the schematic system (Fig. 2) and basic equations (1) to determine the water quality, including the pollution load of sub-basins and the pollution load directly discharged into the Cau River. The basic equation that was used to estimate the WEC is presented below:

$$
C_{x}=\frac{L_{x}}{Q_{x}}=\frac{L_{0} \cdot \exp ^{\left(-k_{D} T_{0}\right)}+\sum_{i=1}^{i=n} l_{i} \cdot \exp ^{\left(-k_{D} t_{i}\right)}+\sum_{i=1}^{i=n+1} L_{i} \cdot \exp ^{\left(-k_{D} T_{i}\right)}}{Q_{x}}
$$

In this equation, $\mathrm{C}_{\mathrm{x}}$ is the concentration at the assessed point $(\mathrm{mg} / \mathrm{l}) ; L_{x}$ is the Pollution load at the assessed point $(\mathrm{g} / \mathrm{s}) ; Q_{x}$ is the river flow rate at the assessed point $\left(\mathrm{m}^{3} / \mathrm{s}\right) ; L_{0}$ is the pollution load unit in the upstream areas, including the existing pollution load $(\mathrm{g} / \mathrm{s}) ; l_{i}$ is the pollution load discharged from the subbasins $(\mathrm{g} / \mathrm{s}) ; L_{i}$ is the pollution load directly discharged into the Cau River $(\mathrm{g} / \mathrm{s}) ; t, T$ are the time taken for flows to reach downstream (days); $k$ is the oxygen consumption rate constant-organic substances decomposition reaction.

\section{RESULTS AND DISCUSSIONS}

\section{Contribution of pollutant loads}

As mentioned above, there are three main catego-

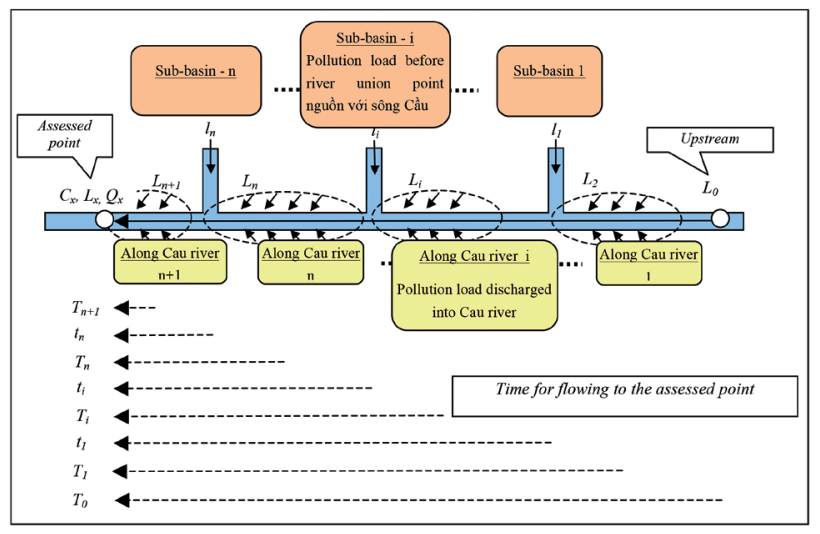

Fig. 2. Schematics of the Streeter-Phelps model. ries of pollutant loads which contribute to the WEC components; these were determined by the following approaches:

Waste water from living activities

The living waste water, which is the product of human activities, was classified as follows:

- Waste water does not include excrement and other sanitation material. This waste water mainly contains suspended solids and detergents. The concentration of organic matter in the waste water is low and not very biodegradable. The levels of inorganic impurities in the waste water are high.

- Waste water contains excrement. This waste water has high levels of bacteria, which may be pathogenic and odorous. The concentration of the organic substances (BOD) and nutrients (such as nitrogen and phosphorus) is high. This waste water is often detrimental to health and easily contaminates the surface water.

- Waste water from kitchens contains grease and wasted food. This type of waste water contains large amounts of organic substances (BOD, COD) and nutrients (such as nitrogen and phosphorus).

The amount of generated waste water fluctuates, and is highly dependent on the conditions of each region, residential scale, drinking water consumption rates and on people's habits. The waste water is estimated to be about $80 \%$ of the supply water. In Vietnam, the normal volume of water supplied to the rural-urban areas is about 80-120 L per person, every day.

The pollutants in waste water can exist in soluble or insoluble forms (easily deposited solids, suspended solids) and the pollutants' composition includes: organic components (52\%), mainly carbohydrates (CHO) such as sugar and cellulose; the grease (CHNO) as volatile fatty acids; proteins (CHOSP) as amino acids, ammonia, and urea $(\mathrm{CHON})_{\mathrm{m}}$ and inorganic acids $(48 \%)$. There are also large numbers of viruses and bacteria. Two basic indicators characterize the pollutant composition in the waste water; they are the suspended solids (TSS) and biological oxygen demand (BOD). According to the guidelines of the World Health Organization (WHO) (Ministry of Natural Resources and Environment, 2012) for developing countries, the pollution load into the environment with the parameters were as shown in Table 1 below:

Waste water from industry

Industrial wastewater is water generated by industrial manufacture facilities and characterized by the production industry. The waste water is different for each type of product and for many different purposes within the production process such as the input raw material, product and machine cooling, solvent, the washing process, the cleaning process etc., thus the industrial waste water contains complex pollutants. It may contain soluble or insoluble substances, organic or inorganic substances. The industrial waste water can be alkaline or acidic, colorless or colored, and may contain grease and toxins.

The industrial development process in recent years in the upper part of the Cau River Basin has contributed 
greatly to the socio-economic development of the region. However, the industrial development process has been strong and has degraded the environment quality. Currently, there are 72 industrial parks and industrial clusters in operation with an area of 3441.363 ha. There are many kinds of industrial plants such as food, mechani-

Table 1. Average pollution load per person according to the WHO

\begin{tabular}{llcc}
\hline No. & Parameter & $\begin{array}{c}\text { Pollution load norm } \\
\text { (g/person/day) }\end{array}$ & $\begin{array}{c}\text { Average pollution } \\
\text { load }\end{array}$ \\
\hline 1 & BOD & $45-54$ & 50 \\
2 & COD & $85-102$ & 94 \\
3 & TS & $170-220$ & 195 \\
4 & TSS & $70-145$ & 107 \\
5 & Grease oil & $0-30$ & 15 \\
6 & Total nitrogen & $6-12$ & 9 \\
7 & Organic nitrogen & $2.4-4.8$ & 3.6 \\
8 & $\mathrm{NH}_{4}{ }^{+}$ & $3.6-7.2$ & 5.4 \\
9 & Total phosphorus & $0.8-4.0$ & 2.4 \\
10 & Total coliform & $10^{6}-10^{10}$ & $10^{8}(\mathrm{MPN} / 100 \mathrm{ml})$ \\
& & $(\mathrm{MPN} / 100 \mathrm{ml})$ &
\end{tabular}

cal, metallurgy, machine and equipment manufacture, textiles, packaging, chemicals, plastics, rubber, etc., concentrated in the four provinces in the upper part of the Cau River Basin.

Most of the industrial parks and industrial clusters are in the process of attracting investors for their construction phase. Thus, to date, most of the industrial parks have not had their infrastructure completed yet. Due to the industrial parks and industrial clusters not having a waste water collection and treatment system, the management and controllers of waste water treatment have faced many difficulties; the status of the waste water remains untreated, and most of the waste water is discharged into the environment.

In addition, a large number of the manufacture facilities that are located outside the industrial parks and clusters have been small and medium enterprises. Some facilities were established long time ago, so the technology is outdated, and the environmental investment is restricted. This is the pollution source that is the most difficult to control and overcome. The waste norms of some untreated industries before they are discharged into the environment according to the WHO are below:

The waste water characteristics of some typical

Table 2. The waste norms of some industries according to the WHO

\begin{tabular}{|c|c|c|c|c|c|c|c|c|}
\hline \multirow[b]{2}{*}{ No. } & \multirow{2}{*}{\multicolumn{2}{|c|}{ Industry }} & \multirow[b]{2}{*}{ Unit (U) } & \multirow{2}{*}{$\begin{array}{c}\text { Waste } \\
\text { amount } \\
\left(\mathrm{m}^{3} / \mathrm{U}\right)\end{array}$} & \multicolumn{4}{|c|}{ Unit (kg/U) } \\
\hline & & & & & $\mathrm{BOD}_{5}$ & TSS & $\begin{array}{c}\text { Total } \\
\text { nitrogen }\end{array}$ & $\begin{array}{c}\text { Total } \\
\text { phosphorus }\end{array}$ \\
\hline \multirow{2}{*}{1} & \multirow{2}{*}{ Milk } & Liquid & Ton/year & 3.1 & 3.21 & 1.5 & 0.31 & 0.68 \\
\hline & & Condensed & Ton/year & 2 & 6.7 & 0.83 & 0.39 & 0.08 \\
\hline \multirow{2}{*}{2} & \multirow{2}{*}{ Paper } & Newspaper & Ton/year & 190 & 7.5 & 2 & & \\
\hline & & Carton & Ton/year & 200 & 15 & 30 & & \\
\hline 3 & Glass & & Ton/year & 45.9 & 2.3 & 690 & & \\
\hline 4 & Chemi & & Ton/year & & 270 & 27 & 54.5 & 7.4 \\
\hline 5 & Rubbe & tire and tube & Ton/year & 37 & 0.4 & 1 & & \\
\hline \multirow{2}{*}{6} & \multirow{2}{*}{ Sugar } & Beet & Ton/year & 23 & 20 & 75 & & \\
\hline & & Sugar-cane & Ton/year & $3-48$ & 2.9 & 6.3 & & \\
\hline
\end{tabular}

Table 3. Waste water characteristics of some typical industries in Vietnam

\begin{tabular}{|c|c|c|c|c|c|c|}
\hline \multirow[b]{2}{*}{ Industry } & \multicolumn{5}{|c|}{ Polluted parameter (mg/l) } & \multirow{2}{*}{$\begin{array}{c}\text { Waste water } \\
\text { amount } \\
\text { ( } \mathrm{m}^{3} / \text { ton of } \\
\text { product) }\end{array}$} \\
\hline & $\begin{array}{l}\mathrm{BOD}_{5} \\
(\mathrm{mg} / \mathrm{l})\end{array}$ & $\begin{array}{c}\mathrm{COD} \\
(\mathrm{mg} / \mathrm{l})\end{array}$ & $\mathrm{SS}(\mathrm{mg} / \mathrm{l})$ & $\begin{array}{l}\text { Total nitrogen } \\
\text { (mg/l) }\end{array}$ & $\begin{array}{c}\text { Total } \\
\text { phosphorus } \\
(\mathrm{mg} / \mathrm{l})\end{array}$ & \\
\hline Aquaculture manufacture & 950 & 1100 & 1400 & 225 & 50 & \\
\hline Food manufacture & 750 & 2184 & 51 & 22.7 & 3.58 & $50-60$ \\
\hline Rubber & 449 & 899 & 152 & 112 & 81 & \\
\hline Beer and wine & 1220 & 1909 & 634 & 79.2 & 4.3 & \\
\hline Textile and dye & $200-480$ & $230-2800$ & $50-350$ & $9-12$ & & \\
\hline Leather & $240-2300$ & $338-5800$ & $350-2900$ & $3.9-12.1$ & $0.9-4.8$ & 50 \\
\hline Wool textile & $120-130$ & $400-450$ & 420 & & & 114 \\
\hline Fiber & $90-130$ & $210-230$ & $800-1300$ & & & 236 \\
\hline Building material & 75 & 110 & 383 & 82.4 & 8 & \\
\hline
\end{tabular}


industries in Vietnam are shown in the table below:

Waste water from agriculture

Although industrialization has occupied a large portion of the provinces in the Cau River Basin, agriculture has still been developing. The agricultural production has been restricted to the rural areas. And now the environment is being increasingly polluted due to the discharge of untreated water from cattle breeding and cultivation. Waste water from cultivation:

Excess water from agricultural irrigation overflows naturally and then spills over into the river system. The amount of water is enormous, and the amount of pollutants from excess fertilizers and other botanical additives is also large. The use of fertilizers and pesticide in agricultural production is aimed at increasing the crop yield, but if used excessively, they have negative impacts on the environment.

Currently, the conventions of using fertilizer and botanical additives in agriculture have mainly been according to the cultivator's judgment. Therefore, dosages are often wrongly estimated (usually overestimated), and leads to environmental pollution. The leached fertilizer and the residual pesticide are toxic to aquatic organisms and are particularly unstable in the environment. Besides, due to the slack management of the authorities, there were many cases of deliberate misuse of agricultural additives to enhance productivity for economic gain.

The norms of the waste load from the fertilizer activities were calculated by the WHO, specifically for developing countries is as follows:

Table 4. The norms of waste load from the cultivation, calculated by the WHO

\begin{tabular}{clcc}
\hline \multirow{2}{*}{ No. } & Pollutant & \multicolumn{2}{c}{ The norm of waste load } \\
\cline { 3 - 4 } & & $\left(\mathrm{kg} / \mathrm{km}^{2} /\right.$ year $)$ & $(\mathrm{kg} / \mathrm{ha} /$ day $)$ \\
\hline 1 & Total nitrogen & 2690 & 0.12 \\
2 & Total phosphorus & 434 & 0.02 \\
\hline
\end{tabular}

\section{Waste water from cattle breeding}

Besides cultivation, the importance of cattle breeding has increased. In recent years, the cattle breeding industry has been growing and improving, Buffalo and poultry breeding have decreased, while that of cows and pigs tended to increase. Cattle breeding has been concentrated in the rural areas, with up to $67 \%$ of farmers having participated in cattle breeding, but mostly on small scales.

Along with the development of cattle breeding, the environmental pollution problems have also been on the rise. Large amounts of wastes such as excrement, leftover food, barn cleaning water, and water from pet bathing have been discharged into the basin. The waste water from the cattle breeding is characterized by high levels of organic compounds, BOD, COD, and suspended solids (TSS). The food wastes, including additives may also contain pollutants, particularly due to their high organic matter content.

Currently, the waste water from these sources has been increasing but the appropriate measures of collection and disposal have still not been implemented. Therefore, it contributes greatly to environmental pollution in rural areas, which can potentially cause diseases in people and animals. The majority of the waste water discharged directly into the watershed (rivers, streams, ponds, lakes, etc.) has been through the sewer system. Controlling the pollution at its source has been very difficult lack of waster water collection systems among the households.

According to the calculations of the WHO for developing countries, the untreated load from cattle and poultry discharged into the environment is as follows:

Table 5. The norms of pollutant load from the cattle breeding according to the WHO

\begin{tabular}{|c|c|c|c|c|}
\hline \multirow{2}{*}{ No. } & \multirow{2}{*}{ Waste } & \multicolumn{3}{|c|}{ Cattle } \\
\hline & & Buffalo, beef & Pig & Poultry \\
\hline 1 & $\begin{array}{l}\text { Waste water } \\
\left(\mathrm{m}^{3} / \mathrm{con} / \text { year }\right)\end{array}$ & 8 & 14.6 & 0.21 \\
\hline \multirow{6}{*}{2} & \multicolumn{4}{|c|}{ Pollution load (kg/con/year) } \\
\hline & $\mathrm{BOD}_{5}$ & 164 & 32.9 & 1.64 \\
\hline & COD & 196.8 & 39.5 & 1.97 \\
\hline & TSS & 1,204 & 73 & 4.2 \\
\hline & Total nitrogen & 43.8 & 7.3 & 3.6 \\
\hline & Total phosphorus & 11.3 & 1.3 & - \\
\hline
\end{tabular}

\section{Computation of surface water flow discharge under different confidence probabilities}

In order to determine the concentration of WEC at five assessment points in the sub-basins and the main river of the Cau River Basin (Fig. 1), the surface water discharges, corresponding to different confidence probabilities of $50 \%, 75 \%, 85 \%, 90 \%$, and 95\%, were computed based on the daily measured values during the period from 1960 to 2014. The results are described in Table 6 . The surface water discharges were considered in order to estimate the self-cleaning capacity of the river basin.

Table 6. Surface water discharge (Q) at the waste sources in the Cau River Basin, corresponding to different confidence probabilities

\begin{tabular}{lcrrrrr}
\hline \multirow{2}{*}{ No. } & $\begin{array}{c}\text { Assessment } \\
\text { points }\end{array}$ & $50 \%$ & $75 \%$ & $85 \%$ & $90 \%$ & $95 \%$ \\
\cline { 3 - 7 } & Upstream & 1.70 & 1.34 & 1.18 & 1.07 & 0.93 \\
1 & Cho Chu & 25.13 & 19.65 & 17.08 & 15.48 & 13.30 \\
2 & Tung $/ \mathrm{s})$ \\
3 & Tuong Nghinh & 46.46 & 91.60 & 31.29 & 28.87 & 27.31 \\
4 & Du & 65.29 & 54.96 & 44.64 & 41.11 & 38.03 \\
5 & Downstream & 79.02 & 66.59 & 54.15 & 49.78 & 45.54 \\
\hline
\end{tabular}


Computed results of the WEC components in the Cau River Basin

The water quality component parameters of total phosphorus (TP), total nitrogen (TN), total suspended solid (TSS), carbon oxygen demand (COD), and the biochemical oxygen demand over five days $\left(\mathrm{BOD}_{5}\right)$, which corresponded to different confidence probabilities of surface water discharge were computed at assessment points using equation (1). In which, the most important pollution loads were estimated based on basic data and the pollution load units of the above three categories. The results in Tables 7, 8, 9, 10, and 11 show that most values of the water quality parameters (TP, TN, TSS,

Table 7. Total phosphorus (TP) at assessment points in the Cau River Basin under different confidence probabilities

\begin{tabular}{rrrrrrr}
\hline \multirow{2}{*}{ No. } & $\begin{array}{c}\text { Assessment } \\
\text { points }\end{array}$ & $50 \%$ & $75 \%$ & $85 \%$ & $90 \%$ & $95 \%$ \\
\cline { 3 - 7 } & Upstream & 0.8 & 1.0 & 1.1 & 1.2 & 1.4 \\
1 & UP (mg/l) \\
2 & Cho Chu & 4.3 & 4.9 & 5.2 & 5.4 & 5.8 \\
3 & Tuong Nghinh & 1.0 & 1.3 & 1.5 & 1.7 & 2.0 \\
4 & Du & 22.8 & 12.5 & 13.5 & 14.2 & 15.70 \\
5 & Downtream & 2.3 & 1.9 & 1.6 & 1.5 & 1.4 \\
\hline
\end{tabular}

Table 8. Total nitrogen ( $\mathrm{TN}$ ) at assessment points in the Cau River Basin under different confidence probabilities

\begin{tabular}{rrrrrrr}
\hline \multirow{2}{*}{ No. } & $\begin{array}{c}\text { Assessment } \\
\text { points }\end{array}$ & $50 \%$ & $75 \%$ & $85 \%$ & $90 \%$ & $95 \%$ \\
\cline { 3 - 7 } & Upstream & 2.9 & 3.7 & 4.2 & 4.6 & 5.2 \\
1 & Cho Chu & 8.2 & 9.2 & 9.7 & 10.1 & 8.2 \\
2 & CN & & \multicolumn{5}{c}{ TN (mg/l) } \\
3 & Tuong Nghinh & 2.1 & 2.6 & 3.0 & 3.3 & 2.1 \\
4 & Du & 22.8 & 25.5 & 27.4 & 28.9 & 31.8 \\
5 & Downstream & 5.4 & 4.9 & 4.3 & 4.2 & 4.1 \\
\hline
\end{tabular}

Table 9. Total suspended solid (TSS) at assessment points in the Cau River Basin under different confidence probabilities

\begin{tabular}{rcrrrrr}
\hline \multirow{2}{*}{ No. } & Assessment & \multicolumn{5}{c}{ TSS (mg/l) } \\
\cline { 3 - 7 } & points & $50 \%$ & $75 \%$ & $85 \%$ & $90 \%$ & $95 \%$ \\
\hline 1 & Upstream & 34.9 & 43.7 & 49.7 & 54.3 & 62.2 \\
2 & Cho Chu & 64.6 & 88.3 & 105.6 & 119.7 & 145.0 \\
3 & Tuong Nghinh & 49.4 & 67.9 & 81.5 & 92.7 & 49.4 \\
4 & Du & 24.6 & 31.2 & 35.7 & 39.2 & 24.6 \\
5 & Downstream & 9.4 & 9.2 & 8.9 & 8.9 & 9.0 \\
\hline
\end{tabular}

$\mathrm{COD}$, and $\mathrm{BOD}_{5}$ ) in the sub-basins of the Cau River (at assessment points No.1, 2, 3 and 4) exceeded the standard values, it indicated that the water quality in the subbasins were heavily polluted and had a low self-cleaning capacity. Whereas, their values at assessment point 5 , which is located downstream of the Cau River, decreased quite quickly.

These phenomena could be explained by the fact that the contribution of pollutant loads from sub-basins exceeded the standard values due to anthropogenic activities such as: (1) Mining exploration in the upstream areas of most sub-basins; (2) Discharge of waste water from settlements. Therefore we can conclude that since

Table 10. Total carbon oxygen demand (COD) at assessment points in the Cau River Basin under different confidence probabilities

\begin{tabular}{rcrrrrr}
\hline \multirow{2}{*}{ No. } & $\begin{array}{c}\text { Assessment } \\
\text { points }\end{array}$ & $50 \%$ & $75 \%$ & $85 \%$ & $90 \%$ & $95 \%$ \\
\cline { 3 - 7 } & Upstream & 30.7 & 38.4 & 43.7 & 47.7 & 54.7 \\
1 & Cho Chu & 56.7 & 77.6 & 92.8 & 105.2 & 56.7 \\
2 & Cuong Nghinh & 43.4 & 59.7 & 71.6 & 81.5 & 43.4 \\
3 & Tuon (mg/l) \\
4 & 36.0 & 42.4 & 46.9 & 50.5 & 36.0 \\
5 & Downstream & 10.4 & 9.8 & 9.2 & 9.1 & 9.1 \\
\hline
\end{tabular}

Table 11. Total five days biochemical oxygen demand $\left(\mathrm{BOD}_{5}\right)$ at assessment points in the Cau River Basin under different confidence probabilities

\begin{tabular}{rcrrrrr}
\hline \multirow{2}{*}{ No. } & $\begin{array}{c}\text { Assessment } \\
\text { points }\end{array}$ & $50 \%$ & $75 \%$ & $85 \%$ & $90 \%$ & $95 \%$ \\
\cline { 3 - 7 } & Upstream & 16.3 & 20.4 & 23.2 & 25.4 & 29.1 \\
1 & Cho Chu & 30.2 & 41.3 & 49.4 & 55.9 & 67.8 \\
2 & Tuong Nghinh & 23.1 & 31.7 & 38.1 & 43.3 & 52.8 \\
3 & Du & 19.6 & 23.0 & 25.3 & 27.2 & 19.6 \\
4 & 6.1 & 5.8 & 5.5 & 5.5 & 6.1 \\
5 & Downstream & & & & & \\
\hline
\end{tabular}

Table 12. Vietnamese technical regulations on surface water quality for irrigation purposes (QCVN 08: 2008/ BTNMT)

\begin{tabular}{cccc}
\hline No. & Indicators & Unit & Standard values \\
\hline 1 & TSS & $\mathrm{mg} / \mathrm{l}$ & 50 \\
2 & $\mathrm{COD}$ & $\mathrm{mg} / \mathrm{l}$ & 30 \\
3 & $\mathrm{BOD}_{5}$ & $\mathrm{mg} / \mathrm{l}$ & 15 \\
4 & $\mathrm{TN}$ & $\mathrm{mg} / \mathrm{l}$ & 1.04 \\
5 & $\mathrm{TP}$ & $\mathrm{mg} / \mathrm{l}$ & 0.3 \\
\hline
\end{tabular}

Table13. Comparison of the measured TP and TN with the values under different confidence probabilities and standard ones

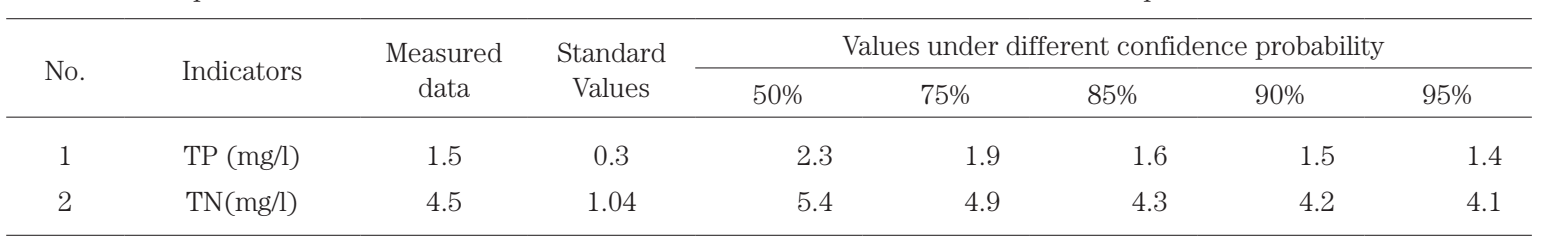


the surface water discharge was supplemented along the main river then its WEC was increased, aided by the river's self-cleaning capacity. However, some important indicators such as TP and TN were still higher than the standard values, therefore, it is necessary to formulate solutions to help reduce their values. There are some feasible methods such as: (1) Implementing optimal integrated management in water management (collecting and treating the waste water from industries, mining, livestock, settlements etc. (2) Applying advanced technology to water treatment and water distribution; (3) Reducing the pollutant loads from agriculture by using the slow release fertilizer such as mixtures of nitrogen, phosphorus, and potassium.

Moreover, the results in these tables also shown that the values of TP, TN, TSS, COD, and BOD5 increase slightly when the confidence probability increases. This phenomenon is expected since, as shown in Table 6, when the confidence probability increased, the surface water discharge decreased, consequently the water quality component parameters (TP, TN, TSS, COD, and $\mathrm{BOD}_{5}$ ) decreased. This means that the self-cleaning capacity of the river decreased.

Additionally, in order to evaluate the accuracy of the computation, the concentration of some water quality components in the downstream (point 5) were compared with average measured values of the year 2014. As shown in the Table. 11, the average measured total concentration of TP and TN are between the values, which were obtained from the confidence probabilities of $75 \%$ and $80 \%$. These results were expected since, in most hydrological years in Vietnam, the surface water discharge that supplies water for irrigation purposes corresponded to the confidence probabilities of $75 \%$ and $80 \%$.

\section{CONCLUSIONS}

This paper introduces a useful model to estimate the water environment capacity in a river basin in the case of lack input data and information: Firstly, input data from areas along the Cau River such as hydrometeorology data and pollutant sources during 2014 were collected. Water quality component parameters, which included total phosphorus (TP), total nitrogen (TN), total suspended solid (TSS), carbon oxygen demand (COD), and the biochemical oxygen demand over five days $\left(\mathrm{BOD}_{5}\right)$ that corresponded to different confidence probabilities of surface water discharge were then computed at some assessment points using the Streeter-Phelps model. Finally, the water environment capacity of this river was assessed by comparing the computed results with the standard values. The results show that most values of the water quality parameters (TP, TN, TSS, COD, and BOD ${ }_{5}$ ) in the sub-basins of the Cau river (at assessment point Nos. 1, 2, 3 and 4) far exceeded the standard values; this indicated that the water in sub-basins were heavy polluted and had low self-cleaning capacities. This could be because the contribution of pollutant loads from subbasins exceeded the standard values. In addition, the computed results were in good agreement with meas- ured values. This indicates that the Streeter-Phelps model is applicable for assessing the pollution levels of the Cau River Basin. The above results served as a useful tool by which managers and authorities can set better goals for different hydrological periods, especially in areas dominated by non-point source pollutants; they also provide researchers with useful input data and information to help deal with the environmental issues in the Cau River Basin.

\section{ACKNOWLEDGEMENTS}

The research is funded by Vietnam National Foundation for Sciences and Technology Development (NAFOSTED) under grand number 105.08-2013.02.

\section{REFERENCES}

Burn. D. H. and E. A. McBean 1985 Optimization modeling of water quality in an uncertain environment, Water Resources Research, 21(7): 934-940

Cao. X. J. and Zhang. H. 2006 Commentary on study of surface water quality model, Journal of Water Resources and Architectural Engineering, 4(4): 18-21

Chinh. L.V., T. T. Lan, N. M. Ha and V. T H. Nghia $2015 \mathrm{a}$ Simulation of Flow Runoff in Cau River Basin by Using GIS Base Distributed Parameter Model, National Annual Conference on Water Resources, Hanoi Water Resources University

Chinh. L.V., L. P. Dong, T. T. Thao, N. T. L. Huong and N. T. Cuu 2015b Study on Simulation and Prediction of Nitrogen Runoff in Cau River Basin by Using GIS Base Distributed Parameter Model, Journal of Science and Technology, University of Natural Science, Vietnam National University 31: 13-21

Dobbins. W. E. 1964 BOD and oxygen relationships in streams, Sanitary Engineering Division, American Society of Civil Engineers, $90(3)$ : 53-78

Lindenschmidt. K., K. Fleischbein, M. Baborowski 2007 Structural uncertainty in a river water quality modeling system. Ecology Modelling, 204: 289-300

Ministry of Natural Resources and Environment of Viet Nam 2012 Technical Report on the Existing of Water Quality in Cau River basin, Viet Nam

Mujumdar. P. P. and Vemula. V. R. S. 2004 Fuzzy waste load allocation model: simulation-optimization approach, Journal of Computing in Civil Engineering, 18(2): 120-131

O'Connor. D. J. 1967 The temporal and spatial distribution of dissolved oxygen in streams, Water Resource Research, 3(1): 65-79

Rinaldi. S. and Soncini-Sessa. R. 1978 Sensitivity analysis of generalized Streeter-Phelps models, Advances in Water Resources, 1(3): 141-146

Riffat R. 2012 Fundamentals of Wastewater Treatment and Engineering, CRC Press, Boca Raton, Fla, USA

Vietnamese technical regulation on surface water quality for irrigation purpose, QCVN 08: 2008/BTNMT.

Shu. S. H., H. Ma 2010 Comparison of two models for calculating water environment capacity of Songhua River. Life Sys Model Intelligent Computation, 6330: 683-90

Thomas. Jr. H. A. 1948 The pollution load capacity of streams, Water Sewage Works, 95: 409-413

Wang. H. D., S. H. Wang, Q. S. Bao, Z. Qi 1995 On regional differentiation of river water environment capacity and strategies to control water environment pollution in China. China Geography Science, 5: 116-24

Wang. J. Q. , Zhong Z., and Wu. J. 2004 Steam water quality models and its development trend, Journal of Anhui Normal University (Natural Science), 27(3): 243-247 